\title{
Discrepancy between Ice Particles and Ice Nuclei in Mixed Clouds: Critical Aspects
}

\author{
Gianni Santachiara ${ }^{1}$, Franco Prodi' ${ }^{1}$ Alessia Nicosia ${ }^{1,2}$, Franco Belosi ${ }^{1}$ \\ ${ }^{1}$ Institute of Atmospheric Sciences and Climate (ISAC), National Research Council, Bologna, Italy \\ ${ }^{2}$ Department of Physics and Earth Sciences, University of Ferrara, Ferrara, Italy \\ Email: f.belosi@isac.cnr.it
}

How to cite this paper: Santachiara, G., Prodi, F., Nicosia, A. and Belosi, F. (2017) Discrepancy between Ice Particles and Ice Nuclei in Mixed Clouds: Critical Aspects. Atmospheric and Climate Sciences, 7, 287297.

http://dx.doi.org/10.4236/acs.2017.73020

Received: March 28, 2017

Accepted: July 2, 2017

Published: July 5, 2017

Copyright $\odot 2017$ by authors and Scientific Research Publishing Inc. This work is licensed under the Creative Commons Attribution International License (CC BY 4.0).

http://creativecommons.org/licenses/by/4.0/

\begin{abstract}
Measurements of ice crystal concentrations in mixed clouds tend to exceed ice nucleus concentrations measured in nearby clear air. This discrepancy is a source of uncertainty in climate change projections as the radiative properties of mixed phase clouds are largely determined by their liquid and ice water content. The ice enhancement process can sometimes depend on secondary ice production, which can occur through ice crystal fracture during sublimation, cloud drop shattering during freezing or following collision with ice particles. However, the discrepancy is observed even in mixed clouds where only primary ice nucleation processes occur. Several hypotheses have been suggested for the observed discrepancies. One factor could be the existence in clouds of pockets of high vapor supersaturation formed by droplet freezing or removal of small droplets by collision with larger droplets, associated with the fact that ice crystal concentration increases with water supersaturation. However, ice crystal concentrations are usually measured at near water saturation. Additional factors could be drop freezing during evaporation and activation of droplet evaporation residues. Here we suggest that a major factor could be underestimation of the contact freezing mode as it is not measured in experimental campaigns and seldom considered in nucleation models. Laboratory experiments give only incomplete answers to the important questions concerning the contact freezing mode, e.g. what fraction of the aerosol particles that come into contact with the droplet surface results in a freezing event and what is the influence of particle type and size, air temperature and relative humidity. As supercooled droplets grow or evaporate in mixed clouds, phoretic forces should play an important role in the collision efficiency between aerosol and droplets, and consequently in contact freezing. A further question is the possibility that aerosol, usually not active in deposition or condensation/immersion freezing, can trigger ice nucleation by colliding with supercooled droplets.
\end{abstract}




\section{Keywords}

Ice Crystal, Ice Nuclei Particles, Ice Nucleation Process, Thermophoresis, Diffusiophoresis

\section{Introduction}

Microphysical processes in clouds are important for cloud evolution, precipitation and the atmospheric environment. Incomplete knowledge of the ice nucleation processes is one of the main obstacles to successful implementation of cloud microphysical models. Ice can form through primary processes (nucleation from the liquid or water vapor phases), homogeneously or heterogeneously triggered by aerosol called ice nuclei particles (INP), and secondary processes that produce ice crystals in the presence of pre-existing ice without requiring the action of ice nucleating particles.

Supercooled droplets are quite common in clouds. Pure micrometric water drops freeze spontaneously (homogeneous process) if the air temperature is below about $-35^{\circ} \mathrm{C}$, while haze droplets freeze at lower temperatures. In the presence of INP, ice formation initiates at a higher temperature than homogeneous nucleation, in a variety of ways: deposition, condensation freezing, immersion freezing and contact freezing. Therefore, in cold clouds at temperatures below $-35^{\circ} \mathrm{C}$, the dominant ice nucleation mode should be homogeneous freezing, while at higher temperatures ice nucleation should take place heterogeneously. Substances have different freezing efficiency depending on the nucleation mode, indicating that the freezing mechanism differs for the different modes, further hindering our understanding of ice formation.

Here we discuss one of the puzzling aspects observed in mixed clouds, where ice particle number concentrations are sometimes much higher than those expected from primary ice nucleating particle concentration measured in nearby clear air. This discrepancy is a source of uncertainty in climate change projections as the radiative properties of mixed phase clouds are largely determined by their liquid and ice water content [1].

\section{Ice Enhancement Processes}

Although the problem of ice enhancement has arisen much interest and debate in cloud physics and several possible explanations for the phenomenon have been proposed, uncertainties remain on which mechanisms are responsible for the high particle concentrations observed in the wide range of cloudy conditions. To try to understand the relationship between ice particles and INP concentrations we will consider previously published papers related to events in which the relatively high ice crystal concentration is not ascribable to secondary ice generation.

\subsection{Primary Ice Production}

Ice crystal number concentrations in mixed clouds tend to exceed ice nucleus 
concentrations in nearby clear air, as determined from standard ice nucleus measuring techniques [2]-[7]. This is particularly evident in clouds with a cloud-top temperature warmer than about $-12^{\circ} \mathrm{C}$ [8] [9] [10] [11]. Several hypotheses have been suggested for the observed discrepancies.

\subsubsection{Water Vapour Supersaturation}

For experimental campaigns not involving artefacts (e.g. ice crystals shattering on the inlet probes during aircraft campaigns) and in secondary ice production, one factor reported in published papers for enhanced nucleation mechanism is the possible existence in clouds of pockets of high vapor supersaturation [3] [12]. It is known that ice crystal concentration increases with water supersaturation Sw. High supersaturation can be related to:

1) Droplet freezing. When ice is nucleated in a supercooled drop, the drop temperature quickly rises to $0^{\circ} \mathrm{C}$ and the drop is a source of heat and water vapor. Large values of Sw can occur around the drop (>10\%), and this may lead enhanced primary ice nucleation [13].

2) Removal of small droplets by collisions with larger droplets during a rising parcel of air [4]. Within this region of high saturation ratio with respect to ice and water (up to 15\%) aerosol particles can be activated as cloud condensation nuclei or even INP, and rapid ice nucleation may occur to produce ice crystal concentrations greatly in excess of those measured by ice nucleus counters, which generally operate close to water saturation. Further processes could help clarify the discrepancy between ice particle and ice nuclei concentrations.

\subsubsection{Drop Freezing during Evaporation}

By considering pure water droplets, Santachiara et al. [14] showed that small ice crystals growing in the presence of supercooled droplets (unstable system) trigger the freezing of fast evaporating droplets (Wegener-Bergeron-Findeisen process) even at much higher temperatures (range $-12^{\circ} \mathrm{C} \div-14^{\circ} \mathrm{C}$ ) than those considered for homogeneous nucleation in stationary conditions. These results support field campaigns, where an increase in ice crystal concentration by factors of 100 - 1000 in less than 10 minutes was observed in the presence of a thin layer of supercooled water drops and a few ice crystals at the top of stratiform, wave and convective clouds (temperatures between $-6^{\circ} \mathrm{C}$ and $-18^{\circ} \mathrm{C}$ ). Rangno and Hobbs [15], studying convective clouds (Marshall Island, in the western Pacific ocean), observed that extremely high concentrations of ice particles (often $>$ $500 \mathrm{l}^{-1}$ ) formed very rapidly at temperatures between $-4^{\circ} \mathrm{C}$ and $-10^{\circ} \mathrm{C}$ and were initiated by the freezing of individual drops. Ansmann et al. [16], in tropical liquid and mixed-phase altocumulus cloud, found that the liquid phase forms first, before ice crystals nucleate in the altocumulus layers, and concluded that ice nucleation starts when evaporating supercooled droplets freeze due to entrainment of dry air. These events could be explained following the previously cited laboratory experiments.

Growth of initial ice crystals can determine homogeneous or heterogeneous freezing (e.g. inside contact) of the droplets as fast evaporation determines a 
high cooling rate [6] [17] [18] [19] [20]. The laboratory results of Santachiara et al. [14] could even help explain the so-called cloud "seeder-feeder" mechanism. In this process, ice crystals from cirrus or higher altocumulus layers fall into lower liquid layers and trigger significant ice production at temperatures that are usually too high for the initiation of heterogeneous ice formation. The "seeder-feeder" mechanism can happen even in mixed cloud where "seeder" and "feeder" zones exist. If ice crystals ("seed crystal") fall through the supercooled liquid water cloud into the lower layers of the cloud ("feeder zone"), they grow due evaporation of droplets or riming, and can even determine their freezing.

\subsubsection{Activation of Droplet Evaporation Residues}

Rosinski and Morgan [21] found that drop evaporation leaves a residual (i.e. a particle soluble, insoluble or mixed) that can subsequently act as ice nuclei if water vapor is supersaturated with respect to ice. Ice formation in the Arctic mixed-phase clouds may be explained by the activation of droplet evaporation residuals, and drop freezing during evaporation [7] [22].

\subsubsection{Underestimation of the Contact Freezing Mode}

Contact freezing is defined as the process in which freezing of a supercooled droplet results from its collision with an aerosol particle. It is known from laboratory experiments that particles acting as contact nuclei nucleate at higher temperatures than particles embedded in non-evaporating drops, and that contact freezing can occur in droplets from the inside-out as well as from the outside-in [23] [24] [25] [26].

In the laboratory, contact freezing can be measured with several devices (cold plate technique, thermal diffusion chamber, electrodynamic balance, wind tunnel, etc), but no instrument has yet been devised to measure all nucleation modes and to isolate contact nucleation in clouds. Laboratory experiments [25] [27] [28] [29] give only incomplete answers to the important questions concerning the contact freezing mode, i.e. are the same ice active sites active in immersion and in the contact freezing mode? What fraction of the aerosol particles that come into contact with the droplet surface result in a freezing event? And what is the influence of particle type and size, air temperature and relative humidity? A summary of the key questions on the impact of contact freezing on cloud glaciation can be found in Ladino et al. [30].

Results reported by Durant and Shaw [24] reveal very similar contact freezing temperatures for volcanic ash, glass-rich volcanic ash and soda glass particles. Fornea et al. [25] found that the most effective contact freezing INP was Pahokeee Peat soil $\left(-10.5^{\circ} \mathrm{C}\right)$, followed by volcanic ash $\left(-11.2^{\circ} \mathrm{C}\right)$, and finally soot $\left(-25.6^{\circ} \mathrm{C}\right)$. Contact freezing activity was found to increase with increasing particle size [28] [31] [32] [33]. Generally speaking, contact nuclei appear to be less dependent than immersion freezing on temperature, aerosol type and droplet size. Several experimental campaigns need to consider contact nucleation in order to account for ice crystal concentration [5] [6] [7] [11] [34].

For experimental evaluation of contact-induced nucleation, it is necessary to 
know the collision efficiency between droplets and aerosol, and select which particles can initiate ice formation (contact nuclei). Liu et al. [35], Lohmann et al. [36] assumed that all dust aerosols can act as contact nuclei. Phillips et al. [37] proposed a contact freezing parameterization by assuming that each ice nucleus particle can nucleate ice at a freezing temperature that is 4.5 higher than the freezing temperature associated with immersion or condensation freezing. Gettelman et al. [38] assumed that only coarse dust aerosols can act as contact ice nuclei.

Concerning the interaction with droplets, aerosol particles can be scavenged from the air by liquid drops through Brownian diffusion, interception, inertial impaction, electroscavenging, thermophoresis and diffusiophoresis (phoretic forces). Experimentally, the collision efficiency can be determined by exposing a droplet to the aerosol flow in the absence of freezing, and then evaporating the droplet and counting the residual aerosol [29] [32]. The freezing efficiency, defined as the freezing probability per droplet-particle collision, can then be derived. Freezing efficiencies obtained with an electrodynamic balance for illite and kaolinite were measured by Hoffmann et al. [32] [33], and Svensson et al. [27] in high, intermediate, and dry conditions. Svensson et al. [27] observed a higher freezing threshold at higher humidity with respect to dry conditions. Niehaus et al. [29] obtained similar freezing efficiency for Arizona test dust, feldspar and rhyolitic ash. For the mineral, an efficiency of about $10^{-5}$, increasing by decreasing temperature, was measured at $-15^{\circ} \mathrm{C}$. Snomax showed a freezing efficiency of $10^{-3}$ at $-5^{\circ} \mathrm{C}$. These results were obtained in the absence of phoretic forces.

However, it is important to note that droplet growth and evaporation in clouds occur frequently, along with concomitant thermo- and diffusiophoretic forces, which act in opposite ways. Thermophoresis pushes particles toward lower temperatures (i.e. towards an evaporating droplet), whereas diffusiophoresis with Stefan flow moves the aerosol in the opposite direction [39]. Therefore, phoretic forces influence collision efficiency and consequently the contact freezing efficiency.

There is disagreement between laboratory experiments and theoretical models concerning the prevalence of thermophoresis or diffusiophoresis when droplet growth or evaporation occurs, thereby increasing the uncertainty in the parameterization model. The impact of phoretic forces is sometimes neglected [35], or only the thermophoretic process is considered, neglecting diffusiophoresis [40] [41], or a prevalence of thermophoresis over diffusiophoresis is assumed. These statements are questionable. Published experiments show a prevalence of Stefan flow with respect to thermophoresis in case of evaporating droplets [42] [43] [44], in disagreement with theoretical papers [45] [46] [47].

Several laboratory experiments show a higher collection efficiency in the Greenfield gap at high with respect to lower Relative Humidity (RH), indicating a prevalence of diffusiophoresis with Stefan flow over thermophoresis. Ladino et al. [48] in experiments performed at $\mathrm{RH}=90 \%$ (droplet evaporating with $\mathrm{d}=$ 
$25.6 \mu \mathrm{m}$ ), showed (Figure 7 of the cited paper) a lower collection efficiency in the Greenfield region with respect to Grower et al.'s model (1977) [46] where Brownian motion and phoretic forces are included, based on a prevalence of thermophoretic force. Ardon-Dreyer [49] found higher collection efficiency in the Greenfield region at high $\mathrm{RH}(88 \%)$ with respect to lower $\mathrm{RH}(11 \%)$ at room temperature $\left(22.5^{\circ} \mathrm{C}\right)$ and a droplet diameter of $43 \mu \mathrm{m}$. Even Svensson et al.'s results [27] should confirm a prevalence of hydrodynamic Stefan flow.

Additional processes can interfere in the contact mode. An important question is whether the homogeneous nucleation process in supercooled water droplets can occur not only in the interior volume of the droplet, but even at or close to its surface [50]. Therefore, contact nuclei could favor surface nucleation. An additional factor that could confirm an underestimation of the contact freezing mode is the possibility that aerosol, usually not active in deposition or condensation/immersion freezing, can trigger nucleation by colliding with supercooled droplets. With respect to this question, an important result was obtained by Niehaus et al. [51] who found that the impact of water soluble salt particles initiated freezing in experiments using water droplets at supercooling temperatures of $9^{\circ} \mathrm{C}$ to $16^{\circ} \mathrm{C}$. These results show that contact freezing nuclei can even be particles not active in deposition or immersion freezing. Figure 1 shows a schematic view of the water nucleation processes suggested to clarify the discrepancy between INP and ice particle concentrations in mixed clouds.

\subsection{Secondary Ice Production}

In several cases, the discrepancy between ice crystals and INP can be explained by considering secondary ice formation processes. Some published papers report that the high concentration of ice is initiated by primary processes such as freezing of individual drops, some of which can fragment upon freezing, accompanied by ice splinter production during riming. Secondary ice formation

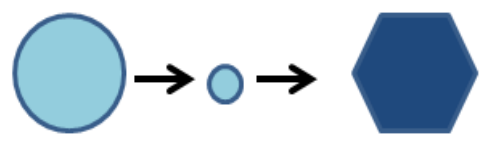

(a)

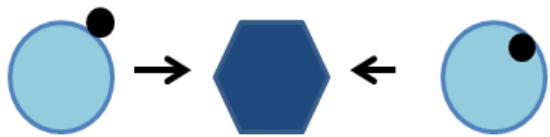

(c)

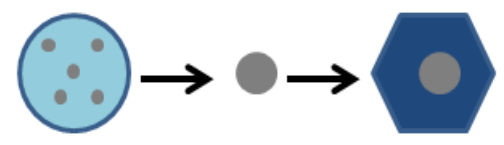

(b)

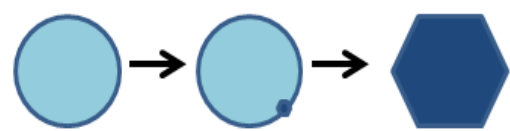

(d)

Figure 1. A schematic view of the water nucleation processes suggested to clarify the discrepancy between INP and ice particle concentrations in mixed clouds. (a) Evaporation freezing; (b) Activation of droplet evaporation residuals; (c) Contact nucleation: contact nucleation can occur in droplets from inside-out, as well as from outside-in; (d) A homogeneous ice nucleation process (pure water or solution droplets) can start on the surface instead of inside the droplets. Symbols: circles (light-blue), water droplets; small circle (grey), residual of droplet evaporation; small circle (black), aerosol particle; hexagon, ice crystal. 
processes can occur through:

1) Fracture of ice crystals during sublimation [52] [53] or following collision of preexisting ice crystals [54];

2) Shattering of large isolated cloud drops during freezing in free fall [55] [56];

3) Hallett-Mossop process, i.e. fragmentation of freezing droplets following their collision with ice particles, e.g. graupels, snowflakes [57] [58] [59].

There is a consensus that the Hallett-Mossop process can occur within a temperature range of approximately $-3^{\circ} \mathrm{C}$ to $-8^{\circ} \mathrm{C}$, requires a $0.2-5 \mathrm{~m} \cdot \mathrm{s}^{-1}$ impaction speed and the presence of cloud drops both smaller than $13 \mu \mathrm{m}$ and larger than $24 \mu \mathrm{m}$. One or more of these processes can be present in the examined clouds [60]. Modeling studies mainly consider only the Hallett-Mossop rime splintering process. A review of secondary ice production can be found in Field et al. [61].

\section{Conclusion}

To help solve the thorny problem of the discrepancy between ice particle and ice nuclei concentrations, laboratory experiments should be extended to shed more light on the processes that control ice initiation, in addition to classical nucleation modes. Future studies should consider the possible activation of droplet evaporation residues, droplet evaporation freezing of pure or solution droplets, the presence of high supersaturation in clouds, and the mechanisms underlying contact nucleation. This should determine the impact of phoretic forces on the collision between aerosol and droplets during growth and evaporation. Additional investigations should address the possibility that aerosol, usually not active in the deposition or condensation/immersion freezing, can trigger nucleation by colliding with supercooled droplets.

\section{References}

[1] Xie, S., Boyle, J., Klein, S.A., Liu, X. and Ghan, S. (2008) Simulations of Arctic Mixed-Phase Clouds in Forecasts with CAM3 and AM2 for M-PACE. Journal of Geophysical Research, 113, Article ID: D04211. https://doi.org/10.1029/2007JD009225

[2] Hobbs, P. and Rangno, A.L. (1985) Ice Particles Concentrations in Clouds. Journal of Atmospheric Sciences, 42, 2523-2549. https://doi.org/10.1175/1520-0469(1985)042<2523:IPCIC>2.0.CO;2

[3] Hobbs, P. and Rangno, A.L. (1990) Rapid Development of High Ice Particles Concentrations in Small Polar Maritime Cumuliform Clouds. Journal of Atmospheric Sciences, 47, 2710-2722. https://doi.org/10.1175/1520-0469(1990)047<2710:RDOHIP>2.0.CO;2

[4] Rangno, A.L. and Hobbs, P.V. (1991) Ice Particle Concentrations and Precipitation Development in Small Polar Maritime Cumuliform Clouds. Quarterly Journal of the Royal Meteorological Society, 117, 207-241.

[5] Field, P.R., Cotton, R.J., Noone, K., Glantz, P., Kaye, P.H., Hirst, E., Greenaway, R.S., Jost, C., Gabriel, R., Reiner, T., Andreae, M., Saunders, C.P.R., Archer, A., Choularton, T., Smith, M., Brooks, B., Hoell, C., Bandy, B., Johnson, D. and Heymsfield, A. (2001) Ice Nucleation in Orographic Wave Clouds: Measurements Made during INTACC. Quarterly Journal of the Royal Meteorological Society, 127, 1493-1512. https://doi.org/10.1002/qj.49712757502 
[6] Baker, B.A. and Lawson, R.P. (2006) In Situ Observations of the Microphysical Properties of Wave, Cirrus and Anvil Clouds. Part I: Wave Clouds. Journal of the Atmospheric Sciences, 63, 3160-3185. https://doi.org/10.1175/JAS3802.1

[7] Fridlind, A.M., Ackerman, A.S., McFarquhar, G., Zhang, G., Poellot, M.R., DeMott, P.J., Prenni, A.J. and Heymsfield, A.J. (2007) Ice Properties of Single-Layer Stratocumulus during the Mixed-Phase Arctic Cloud Experiment: 2. Model Results. Journal of Geophysical Research, 112, Article ID: D24202.

https://doi.org/10.1029/2007JD008646

[8] Koenig, L.R. (1963) The Glaciating Behaviour of Small Cumulonimbus Clouds. Journal of Atmospheric Sciences, 20, 29-47. https://doi.org/10.1175/1520-0469(1963)020<0029:TGBOSC >2.0.CO;2

[9] Koenig, L.R. (1968) Some Observations Suggesting Ice Multiplication in the Atmosphere. Journal of Atmospheric Sciences, 25, 460-463. https://doi.org/10.1175/1520-0469(1968)025<0460:SOSIMI >2.0.CO;2

[10] Cooper, W.A. (1986) Ice Initiation in Natural Clouds. In: Cooper, W.A., et al., Eds., Precipitation Enhancement: A Scientific Challenge, American Meteorological Society, Boston, 29-32. https://doi.org/10.1007/978-1-935704-17-1_4

[11] Sassen, K., DeMott, P.J., Prospero, J.M. and Poellot, M.R. (2003) Saharan Dust Storms and Indirect Aerosol Effects on Clouds: CRYSTAL-FACE Results. Geophysical Research Letters, 30, 1633. https://doi.org/10.1029/2003GL017371

[12] Mizuno, H. and Fukuta, N. (1995) Natural Ice Nucleus Measurement under High Supersaturation. Journal of the Meteorological Society of Japan, 73, 1115-1122. https://doi.org/10.2151/jmsj1965.73.6_1115

[13] Rosinski, J. (1979) The Role of Natural and Man-Made Ice-Forming Nuclei in the Atmosphere. Advances in Colloid and Interface Science, 10, 315-367. https://doi.org/10.1016/0001-8686(79)87010-4

[14] Santachiara, G., Belosi, F. and Prodi, F. (2014) The Mystery of Ice Crystal Multiplication in a Laboratory Experiment. Journal of Atmospheric Sciences, 71, 89-97. https://doi.org/10.1175/JAS-D-13-0117.1

[15] Rangno, A.L. and Hobbs, P.V. (2005) Microstructures and Precipitation Development in Cumulus and Small Cumulonimbus Clouds over the Warm Pool of Tropical Pacific Ocean. Quarterly Journal of the Royal Meteorological Society, 131, 639-673. https://doi.org/10.1256/qj.04.13

[16] Ansmann, A., Tesche, M., Seifert, P., Althausen, D., Engelmann, R., Fruntke, J., Wandinger, U., Mattis, I. and Müller, D. (2009) Evolution of the Ice Phase in Tropical Altocumulus: SAMUM Lidar Observations over Cape Verde. Journal of Geophysical Research, 114, Article ID: D17208. https://doi.org/10.1029/2008JD011659

[17] Jung, S., Tiwari, M.K., Doan, N.V. and Poulikakos, D. (2012) Mechanism of Supercooled Droplet Freezing on Surfaces. Nature Communications, 3, 613. https://doi.org/10.1038/ncomms1630

[18] Cooper, W.A. (1995) Ice Formation in Wave Clouds: Observed Enhancement during Evaporation. In: American Meteorological Society, Ed., Preprint of Proceedings of the AMS Conference on Cloud Physics, Dallas, Texas. American Meteorological Society, Boston, 147-152.

[19] De Boer, G., Morrison, H., Shupe, M.D. and Hildner, R. (2011) Evidence of Liquid Dependent Ice Nucleation in High-Latitude Stratiform Clouds from Surface Remote Sensors. Geophysical Research Letters, 38, Article ID: L01803. https://doi.org/10.1029/2010GL046016

[20] Lawson, R.P. and Woods, S. (2015) The Microphysics of Ice and Precipitation Development in Tropical Cumulus Clouds. Journal of Atmospheric Sciences, 72, 
2429-2445. https://doi.org/10.1175/JAS-D-14-0274.1

[21] Rosinski, J. and Morgan, G. (1991) Cloud Condensation Nuclei as a Source of Ice-Forming Nuclei in Clouds. Journal of Aerosol Science, 22, 123-133. https://doi.org/10.1016/0021-8502(91)90022-A

[22] Fan, J., Ovtchinnikov, M., Comstock, J.M., McFarlane, S.A. and Khain, A. (2009) Ice Formation in Arctic Mixed-Phase Clouds: Insights from a 3-D Cloud-Resolving Model with Size-Resolved Aerosol and Cloud Microphysics. Journal of Geophysical Research, 114, Article ID: D04205. https://doi.org/10.1029/2008JD010782

[23] Gokhale, N.R. and Goold, J. (1968) Droplet Freezing by Surface Nucleation. Journal of Applied Meteorology, 7, 870-874. https://doi.org/10.1175/1520-0450(1968)007<0870:DFBSN >2.0.CO;2

[24] Durant, A.J. and Shaw, R.A. (2005) Evaporation Freezing by Contact Nucleation Inside-Out. Geophysical Research Letters, 32, Article ID: L20814. https://doi.org/10.1029/2005GL024175

[25] Fornea, A.P., Brooks, S.D., Dooley, J.B. and Saha, A. (2009) Heterogeneous Freezing of Ice on Atmospheric Aerosols Containing Ash, Soot, and Soil. Journal of Geophysical Research, 114, Article ID: D13201. https://doi.org/10.1029/2009jd011958

[26] Niehaus, J., Bunker, K.W., China, S., Kostinski, A., Mazzoleni, C. and Cantrell, W. (2014) A Technique to Measure Ice Nuclei in the Contact Mode. Journal of Atmospheric and Oceanic Technology, 31, 913-922. https://doi.org/10.1175/JTECH-D-13-00156.1

[27] Svensson, E.A., Delval, C., von Hessberg, P., Johnson, M.S. and Pettersson, J.B.C. (2009) Freezing of Water Droplets Colliding with Kaolinite Particles. Atmospheric Chemistry Physics, 9, 4295-4300. https://doi.org/10.5194/acp-9-4295-2009

[28] Ladino, L.A., Stetzer, O., Luond, F., Welti, A. and Lohmann, U. (2011) Contact Freezing Experiments of Kaolinite Particles with Cloud Droplets. Journal of Geophysical Research, 116, Article ID: D22202. https://doi.org/10.1029/2011jd015727

[29] Niehaus, J., Becker, J.G., Kostinski, A. and Cantrell, W. (2014) Laboratory Measurements of Contact Freezing by Dust and Bacteria at Temperatures of MixedPhase Clouds. Journal of Atmospheric Sciences, 71, 3659-3667. https://doi.org/10.1175/JAS-D-14-0022.1

[30] Ladino, L.A., Stetzer, O. and Lohmann, U. (2013) Contact Freezing: a Review of Experimental Studies. Atmospheric Chemistry and Physics, 13, 9745-9768. https://doi.org/10.5194/acp-13-9745-2013

[31] DeMott, P.J. (1995) Quantitative Description of Ice Formation Mechanisms of Silver Iodide-Type Aerosols. Atmospheric Research, 38, 63-99. https://doi.org/10.1016/0169-8095(94)00088-U

[32] Hoffmann, N., Kiselev, A., Rzesanke, D., Duft, D. and Leisner, T. (2013) Experimental Quantification of Contact Freezing in an Electrodynamic Balance. Atmospheric Measurement Techniques, 6, 2373-2382. https://doi.org/10.5194/amt-6-2373-2013

[33] Hoffmann, N., Duft, D., Kiselev, A. and Leisner, T. (2013) Contact Freezing Efficiency of Mineral Dust Aerosols Studied in an Electrodynamic Balance: Quantitative Size and Temperature Dependence for Illite Particles. Faraday Discussions, 165, 383-390. https://doi.org/10.1039/c3fd00033h

[34] Morrison, H., Shupe, M.D., Pinto, J.O. and Curry, J.A. (2005) Possible Roles of Ice Nucleation Mode and Ice Nuclei Depletion in the Extended Lifetime of Arctic Mixed-Phase Clouds. Geophysical Research Letters, 32, Article ID: L18801. https://doi.org/10.1029/2005gl023614 
[35] Liu, X., Penner, J.E., Ghan, S.J. and Wang, M. (2007) Inclusion of Ice Microphysics in the NCAR Community Atmospheric Model Version 3 (CAM3). Journal of Climate, 20, 4526-4547. https://doi.org/10.1175/JCLI4264.1

[36] Lohmann, U. (2002) Possible Aerosol Effects on Ice Clouds via Contact Nucleation. Journal of Atmospheric Sciences, 59, 647-656. https://doi.org/10.1175/1520-0469(2001)059<0647:PAEOIC>2.0.CO;2

[37] Phillips, V.T.J., DeMott, P.J. and Andronache, C. (2008) An Empirical Parameterization of Heterogeneous Ice Nucleation for Multiple Chemical Species of Aerosol. Journal of Atmospheric Sciences, 65, 2757-2783. https://doi.org/10.1175/2007JAS2546.1

[38] Gettelman, A., Liu, X., Ghan, J., Morrison, H., Park, S., Conley, A.J., Klein, S.A., Boyle, J., Mitchell, D.L. and Li, J.-L.F. (2010) Global Simulations of Ice Nucleation and Ice Supersaturation with an Improved Cloud Scheme in the Community Atmosphere Model. Journal of Geophysical Research, 115, Article ID: D18216. https://doi.org/10.1029/2009JD013797

[39] Stefan, J. (2006) Üeber Die Verdampfung Aus Einem Kreisförming Oder Elliptisch Begrenzten Becken. Annalen der Physik, 253, 550-560.

https://doi.org/10.1002/andp.18822531108

[40] Beard, K.V. (1992) Ice Initiation in Warm-Base Convective Clouds: An Assessment of Microphysical Mechanisms. Atmospheric Research, 28, 125-152. https://doi.org/10.1016/0169-8095(92)90024-5

[41] Cotton, R.J. and Field, P.R. (2002) Ice Nucleation Characteristics of an Isolated Wave Clouds. Quarterly Journal of the Royal Meteorological Society, 128, $2417-$ 2437. https://doi.org/10.1256/qj.01.150

[42] Vittori, O.A. and Prodi, V. (1967) Scavenging of Atmospheric Particles by Ice Crystals. Journal of Atmospheric Sciences, 24, 533-538. https://doi.org/10.1175/1520-0469(1967)024<0533:SOAPBI>2.0.CO;2

[43] Rosinski, J. (1967) A Possible Role of Ice-Forming Nuclei in Rain Formation. Journal of Applied Meteorology, 6, 1062-1065. https://doi.org/10.1175/1520-0450(1967)006<1062:APROIF>2.0.CO;2

[44] Prodi, F., Santachiara, G., Belosi, F., Vedernikov, A. and Balapanov, D. (2014) Phoretic Forces on Aerosol Particles Surrounding an Evaporating Droplet in Microgravity Conditions. Atmospheric Research, 142, 40-44. https://doi.org/10.1016/j.atmosres.2013.09.001

[45] Slinn, W.G.N. and Hales, J.M. (1971) A Reevaluation of the Role of Thermophoresis as a Mechanism of In- and Below-Cloud Scavenging. Journal of Atmospheric Sciences, 28, 1465-1471. https://doi.org/10.1175/1520-0469(1971)028<1465:AROTRO >2.0.CO;2

[46] Grover, S.N., Pruppacher, H.R. and Hamielec, E. (1977) A Numerical Determination of the Efficiency with Which Spherical Aerosol Particles Collide with Spherical Water Drops Due to Inertial Impaction and Phoretic and Electrical Forces. Journal of Atmospheric Sciences, 34, 1655-1663. https://doi.org/10.1175/1520-0469(1977)034<1655:ANDOTE $>2.0 . C O ; 2$

[47] Wang, P.K., Grover, S.N. and Pruppacher, H.R. (1978) On the Effect of Electric Charges on the Scavenging of Aerosol Particles by Clouds and Small Raindrops. Journal of Atmospheric Sciences, 35, 1735-1743. https://doi.org/10.1175/1520-0469(1978)035<1735:OTEOEC >2.0.CO;2

[48] Ladino, L., Stetzer, O., Hattendorf, B., Günther, D., Croft, B. and Lohmann, U. (2011) Experimental Study of Collection Efficiencies between Submicron Aerosols and Cloud Droplets. Journal of Atmospheric Sciences, 68, 1853-1864. 
https://doi.org/10.1175/JAS-D-11-012.1

[49] Ardon-Dreyer, K., Huang, Y.-W. and Cziczo, D.J. (2013) Experimental Assessment of Collection Efficiency of Submicron Aerosol Particles by Cloud Droplets Using the New MIT-CFC. 14th Conference on Cloud Physics and Atmospheric Radiation, , American Meteor Society, Boston, MA, 6 July 2014.

[50] Tabazadeh, A., Djikaev, Y.S. and Reiss, H. (2002) Surface Crystallization of Supercooled Water in Clouds. Proceeding of the National Academy of Sciences of the United States of America, 99, 15873-15878. https://doi.org/10.1073/pnas.252640699

[51] Niehaus, J. and Cantrel, W. (2015) Contact Freezing of Water by Salts. Journal of Physical Chemistry Letters, 6, 3490-3495. https://doi.org/10.1021/acs.jpclett.5b01531

[52] Oraltay, R.G. and Hallett, J. (1989) Evaporation and Melting of Ice Crystals: A Laboratory Study. Atmospheric Research, 24, 169-189. https://doi.org/10.1016/0169-8095(89)90044-6

[53] Bacon, N.J., Swanson, B.D., Baker, M.C. and Davis, E.J. (1998) Breakup of Levitated Frost Particles. Journal of Geophysical Research, 103, 13763-13775. https://doi.org/10.1029/98JD01162

[54] Vardiman, L. (1978) The Generation of Secondary Ice Particles in Clouds by Crystal-Crystal Collision. Journal of Atmospheric Sciences, 35, 2168-2180. https://doi.org/10.1175/1520-0469(1978)035<2168:TGOSIP>2.0.CO;2

[55] Hobbs, P.V. and Alkezweeny, A.J. (1968) The Fragmentation of Freezing Water Droplets in Free Fall. Journal of Atmospheric Sciences, 25, 881-888. https://doi.org/10.1175/1520-0469(1968)025<0881:TFOFWD>2.0.CO;2

[56] Leisner, T., Pander, T., Handmann, P. and Kiselev, A. (2014) Secondary Ice Processes upon Heterogeneous Freezing of Cloud Droplets. 14th Conference on Cloud Physics and Atmospheric Radiation, American Meteorological Society, Boston, MA, 6 July 2014.

[57] Hallett, J. and Mossop, S.C. (1974) Production of Secondary Ice Particles during the Riming Process. Nature, 249, 26-28. https://doi.org/10.1038/249026a0

[58] Mossop, S.C. (1985) Secondary Ice Particle Production during Rime Growth: The Effect of Drop Size Distribution and Rimer Velocity. Quarterly Journal of the Royal Meteorological Society, 111, 1113-1124. https://doi.org/10.1002/qj.49711147012

[59] Takahashi, T., Nagao, Y. and Kushiyama, Y. (1995) Possible High Ice Particles Production during Graupel-Graupel Collisions. Journal of Atmospheric Sciences, 52, 4523-4527. https://doi.org/10.1175/1520-0469(1995)052<4523:PHIPPD>2.0.CO;2

[60] Hobbs, P.V., Rangno, A.L., Shupe, M. and Uttal, T. (2001) Airborne Studies of Cloud Structures over the Arctic Ocean and Comparison with Retrievals from Ship-Based Remote Sensing Measurements. Journal of Geophysical Research, 106, 15029-15044. https://doi.org/10.1029/2000JD900323

[61] Field, P.R., et al. (2016) Chapter 7. Secondary Ice Production-Current State of the Recommendations for the Future. In: American Meteorological Society, Ed., $\mathrm{Me}$ teorological Monographs, American Meteorological Society, Boston, 7.1-7.20. 
Submit or recommend next manuscript to SCIRP and we will provide best service for you:

Accepting pre-submission inquiries through Email, Facebook, LinkedIn, Twitter, etc. A wide selection of journals (inclusive of 9 subjects, more than 200 journals)

Providing 24-hour high-quality service

User-friendly online submission system

Fair and swift peer-review system

Efficient typesetting and proofreading procedure

Display of the result of downloads and visits, as well as the number of cited articles Maximum dissemination of your research work

Submit your manuscript at: http://papersubmission.scirp.org/

Or contact acs@scirp.org 